consultative functions in respect of reserves held or administered by local authorities. The central body "should be distinct from, and have equal and parallel status with, the National Parks authority", the establishment of which has been recommended by successive Government committees. Whatever the administrative machinery, however, the paramount need for continuous scientific supervision cannot be too strongly emphasized.

\section{COAL UTILIZATION RESEARCH AND THE NATIONAL ECONOMY}

$\mathrm{T}$

$\mathrm{HE}$ emergence of coal as a factor of major importance in the war effort of the United Nations is one of the outstanding features of the times. Its importance in Great Britain alone can be measured by the establishment of a Ministry of Fuel and Power, concerned not merely with production but also with utilization of fuel. The Parliamentary and Scientific Committee-a non-party and unofficial body formed to link scientific workers with members of Parliament - has attempted to bring matters to a focus at a meeting on May 4 in the House of Commons, when a report on "Coal Utilisation Research and the National Economy" was adopted. Members of both Houses and others concerned with technical and scientific bodies have joined in its preparation. Statements had been received from experts and also.from Major Lloyd George, Minister of Fuel and Power. Copies of the report have been sent to the Lord President of the Council and other Ministers in the hope that they might agree to receive a deputation to discuss the implementation of the proposals.

The report stresses the fact that the life of Great Britain as an industrial nation depends on the supply of energy and raw materials for manufacture. Our climate necessitates the use of large quantities of artificial warmth. The declining productivity of our collieries, it is asserted, must be offset by increased efficiency of utilization. New industries must be created to secure us against unemployment and develop exports. "All these vital objectives demand coal research on a scale never before contemplated in this or any other country. Coal researeh is an investment which will repay this country handsomely."

The report includes a review of the fuel situation as it may appear after the War, in the light of needs and the present position of fuel technology. In general, the arguments are not new but repeated with greater vigour and urgency than hitherto, and it is instructive to look back and recall how they were received and treated in former times. Royal Commissions in succession have found that the national resources of coal are a wasting and, so far as the choicest and most accessible seams in Great Britain are concerned, a wasted asset. In the, early days of this century a gentle effort was made to control the export of coal by means of a small coal tax. This raised economic problems, and in an age when trade had to be kept very free, the tax was shortlived. This indicates an important characteristic of the history of the coal industry. Coal has been regarded by the industry as a commodity to be bought and sold, not as a precious material, capable by means of scientific artistry of being fashioned into an infinity of new forms. The War of 1914-18 found the coal trade, actuated by commercial instincts, sinking. costly new pits to achieve expanding exports-which, in the event, have not been realized.

Scientific men even then knew that Great Britair would some day have to cultivate greater thrift in the use of coal, and that this thrift would only be achieved by the application of scientific effort. So far back as 1906, the University of Leeds established a professorship of fuel technology, and in succeeding years the example has been followed to a greater or less extent in other universities. Considering their resources, fuel technicians of the past generation can view with satisfaction the results of their efforts, whether on the chemical or the engineering side, as is shown by figures given in the present report. Fuel problems are world-wide and, broadly speaking, there is no absolute secrecy about them. Ideas or achieve. ments in one country can be adopted all over the world if those concerned choose-which is not always done. For example, enthusiasts for smoke abatement have never ceased to make their advocacy heard and yet, since women received the vote, they have not used their political power to bring forward the smokeless city:

Experience shows that there may be a considerable lag between the gaining of technical knowledge and its applications. In Great Britain, the tradition of individual liberty may even cause a retardation of technical progress. The coal-producing industry-employed and employers-has not helped. Left by the War of 1914-18 saddled with unremunerative collieries, it passed through a period of strife and even passive resistance to fuel efficiency, which led in one mining town to the prohibition of the use of gas-heated wash boilers in favour of coal-the object of efficiency in domestic heating took second place to the maintenance of sales. That this 'raw coal' mind still exists appears from the report itself, which links a plea for the burning of raw coal in domestic fires with far-reaching plans for chemical researches on coal. The chemical values in coal are likely to reside largely if not mainly in the volatile matter, which ought not to be ruthlessly burnt.

At one time, the cost of liquid fuel in Great Britain fell so far that imported mineral oil began to make serious inroads into the normal provinces of coal. In one large city in a mining area with idle pitworkers, a municipal building planned for oil-fired central heating was erected. The gas industry, dealing in a fuel which is above all mobile, has remained organized on almost parochial lines, while the uncontrolled competition between gas and electricity has allowed a waste of capital in the supply services. In addition, the country passed through a period of economic slump, which promoted conservatism, or rather conservation, of old plant and equipment.

The remarks above give just a few examples to 
show how the application of technical progress may be retarded, especially when the habits and traditions of a nation are involved, as with its methods of heating. It may be a case requiring national action, but State action though powerful is slow. It required the War of 1914-18 to bring about the national Physical and Chemical Survey of Coal Resources of Great Britain. It has required a second World War to evoke a Ministry of Fuel and Power to step in and control or promote efficiency in utilization. This action, which would have seemed revolutionary a few years ago, is a logical consequencs of the fuel survey and its revelations of shortages--especially of certain kinds of coal. This, fuel economy campaign, launched to secure savings for the war effort, has already had considerable success in stopping the grosser wastes. It provides'a survey of utilization conditions in general, and reveals that industry, including the large consumer, if wasteful of fuel, is usually wasteful involuntarily, because it is usually unaware of the inefficiency of its fuel-using installa. tions.

This ignorance of conditions of combustion is unavoidable so long as it is permissible for plant to be installed unprovided with any sort of provision for scientific control. The action of the Ministry's technical staff has aroused increased attention to combustion control, and must, if continued after the War, lead to notable permanent fuel saving. It is an example of beneficent State action which calls merely for the application in industrial practice of existing knowledge, without awaiting the results of long-term research.

This does not preclude the concurrent developinent of fuel research in Great Britain as widely as is possible or effective. Experiment on a large scale is certain to be slow and may have to await the completion of small-scale preparatory work. The fact that all this takes time is a ground for making an early start. Fuel research is in active progress the whole world over, so that a flood of revolutionary results is not to be expected. Nevertheless, there is always the possibility that men of imagination will make discoveries, but only if they are given the opportunity.

The report makes a survey of the desirable aims for experiment, extending from the cleaning of coal to the preparation of synthetic resins and high-grade aviation spirit-all from coal. The proposals are marked by a prominent interest in the use of raw coal rather out of harmony with the use of coal as a raw material for the manufacture of chemicals. For this latter purpose, it is of course necessary to break up the coal mass into its constituent radicals, which are capable of reassembly to form new and desirable structures. It is very reasonably suggested in the report that an object for a national research policy would be the conversion of coal into fluid fuels (free from ash and sulphur) to the greatest possible extent. It is already permissible to envisage this as a possibility, worthy of a great national effort, to which all the other aspects of coal research now in progress in Great Britain would play a subsidiary part.

\section{APOLOGETIC, OLD AND NEW}

\section{Princeps Concordia}

Pico della Mirandola and the Scholastic Tradition By Avery Dulles. (Harvard Phi Beta Kappa Prize Essay for 1940.) Pp. xiii + 182. (Cambridge, Mass. Harvard University Press ; London : Oxford Univer sity Press, 1941.) 11s. 6d. net.

\section{Science, Christianity and Truth}

By the Rev. Canon A. E. Baker. Pp. 158. (London Eyre and Spottiswoode, Ltd., 1943.) 6s. net.

\section{HERE might not at first sight appear to be very} much in common between Mr. Avery Dulles able and scholarly monograph on the fifteenth century Italian philosopher, Pico della Mirandola (1463-1494), and Canon A. E. Baker's work of modern popular Christian apologetic ; yet it is surprising to find how little the development of the natural sciences has affected the fundamental problems of religion and philosophy. This is all the more remarkable because Mr. Dulles, by his careful examination of the writings of Pico, makes it clear that this philosopher of the Renaissance was not, as some students of his work have maintained, a humanist of the modern type, nor yet an idealist of the Neo-Platonic tradition, still less a Hegel born out of due time. Fundamentally, he was a scholastic, belonging to the medieval rather than the modern tradition, the cleavage between these two being less sharp, in point of fact, than has often been supposed. At the Universities of Padua and Paris, but especially at the former, which in the fifteenth century had become the metropolis of scholasticism, Pico came into fruitful contact with the thought of the medieval philosophers. All his thinking is done in terms of scholasticism, which was by no means the barren fig-tree it has been pictured.

Mr. Dulles has two chapters on Pico's ontology, or theory of being : the first on the ontology of contingent beings, and the second on that of the necessary Being and His existence. In the former chapter it is very interesting to compare Pico's theories about matter with those of modern physics so lucidly stated by Canon Baker in his chapter, "The Story of the Universe". Pico, following Aristotle and Aquinas, was firmly opposed to the idea that formless matter could be real. To affirm the non-reality of matter apart from form is not so far removed from the saying of Sir Arthur Eddington, quoted by Canon Baker at the head of his chapter on modern physical theories: "I am convinced that if in physics we pursued to the bitter end our attempts to reach purely objective reality, we should simply undo the work of creation". Matter and form may both be abstractions from a unity which is indivisible, but the scholastics had in their dichotomy of matter and form an instrument of thought which enabled them to interpret being at all its levels. Pico, Mr. Dulles writes, "saw the whole universe as a hierarchy descending from the simplicity and sovereign reality of Pure Act at the summit, to the virtual nothingness of prime matter at the base".

In his remarkable chapter, "Is There a God ?", Canon Baker writes :

"If there be no other ground and cause of existence than the irrational, the meaningless, the unconscious, the blind, then there is no reason to believe that our reasoning arrives at truth rather than error. Particles of matter in motion, the discharge of quasi-electric forces along the paths of least resistance in the brain, determine all our thoughts." 